\title{
Reliability intra-and inter-examiner of the head postural assessment by computerized photogrammetry
}

\author{
Confiabilidade inter e intraexaminador da avaliação postural da cabeça por \\ fotogrametria computadorizada
}

\author{
Confiabilidad inter e intra-examinador de la evaluación postural de la cabeza \\ por fotogrametría computarizada
}

Paula Rossi Carneiro', Bárbara dos Santos Cardoso², Caroline Modesto da Cunha³, Lídia Cristina da Silva Teles ${ }^{4}$

\begin{abstract}
I Scientific articles about reliability of photogrammetry for cervical spine posture evaluation are infrequent. The aim of the present investigation is to verify intra-and inter-examiner reliability of the computerized photogrammetry method for head postural evaluation in lateral view. Twenty-five young women, between 20 and 30 years old, were positioned seated in an upright position and photographed in lateral view. The photographs were imported to Corel Draw X13 program for postural evaluation by computerized photogrammetry. Analyses of intra-and inter-examiner reliability were performed for the angles: condyle-acromion (ACA), menton-sternum (AME) and Frankfurt (AF). The photogrammetry was performed by two examiners: EA and EB. For intra-examiner analyses, EA assessed the pictures twice (A1 and A2) for the same angles within 3 months. For the inter-examiner analyses, EB performed the photogrammetry for the same angles (B1) in order to compare with the data from EA. Using the interclass correlation coefficient (ICC) we observed an excellent correlation in the intra-examiner analysis ( $\mathrm{A} 1$ and A2) for the angles: ACA and AME (both with ICC=1.0); and $A F(I C C=0.78)$. For the inter-examiner analyses between $A 1$ and B1, it was observed: $A C A(I C C=0.24), A M E(I C C=0.26)$ and $A F(I C C=0.00)$. For the comparison between $A 2$ and
\end{abstract}

B1, the ICC values were: 0.23 ; 0.27 and 0.00 , respectively for ACA, AME and AF, classified as weak correlations. In conclusion, the photogrammetry is reliable when performed by the same examiner. The inter-examiner assess showed low reliability, what could have been compromised by the reduced experience of the EB in applying the method.

Keywords I Photogrammetry; Posture; Reproducibility of Results.

RESUMO I A literatura sobre confiabilidade da fotogrametria para avaliação postural cervical é escassa. O objetivo do presente estudo é verificar a confiabilidade inter e intraexaminador da fotogrametria computadorizada para a avaliação postural da cabeça em vista lateral. Vinte e cinco mulheres jovens foram posicionadas sentadas com a coluna ereta e fotografadas em vista lateral. As fotografias foram importadas pelo programa Corel Draw X3 para a avaliação postural por fotogrametria computadorizada. As análises de confiabilidade intra e interexaminadores foram realizadas para os ângulos: côndilo-acrômio (ACA), mento-esternal (AME) e de Frankfurt (AF). A fotogrametria foi realizada por dois examinadores: EA e EB. Para a análise intraexaminadores o EA fez a avaliação das fotos das participantes duas vezes (A1 e A2) para os mesmos ângulos

Study conducted at the Laboratório de Voz da Clínica de Fonoaudiologia of the Faculdade de Odontologia de Bauru, Universidade de São Paulo (USP) - Bauru (SP), Brazil.

${ }^{1}$ Graduate Program in Bioengeneering at USP - São Carlos (SP), Brazil.

${ }^{2}$ Faculdade Anhanguera de Bauru - Bauru (SP), Brazil.

${ }^{3}$ Graduate Program in Fisioterapia Geriátrica na Universidade Federal de São Carlos (UFSCar) - São Carlos (SP), Brazil.

${ }^{4}$ Speech Language Pathology Department at USP - Bauru (SP), Brazil. 
em um intervalo de três meses. Para a análise interexaminadores o EB avaliou a fotogrametria dos mesmos ângulos (B1), que foi comparada com os dados do EA. Avaliando o coeficiente de correlação interclasse (CCl), observamos que houve correlação excelente na análise intraexaminador (A1 e A2) com CCl=1,0 para os ângulos ACA e AME e CCl=0,78 para AF. Houve fraca correlação na análise interavaliadores A1 e B1 com CCl de 0,24 e 0,26 e entre $\mathrm{A} 2$ e $\mathrm{B} 1$ com $\mathrm{CCl}$ de 0,23; 0,27 e 0,00 para os ângulos ACA, AME e AF, respectivamente. Conclui-se que a fotogrametria é confiável quando realizada pelo mesmo avaliador. A avaliação interexaminador apresentou baixa confiabilidade, o que pode ter sido comprometida pela reduzida experiência do EB na aplicação do método.

\section{Descritores I Fotogrametria; Postura; Reprodutibilidade dos Testes.}

RESUMEN I La literatura acerca de la confiabilidad de la fotogrametría para la evaluación postural cervical es escasa. El objetivo del presente estudio es verificar la confiabilidad inter e intra-examinador de la fotogrametría computadorizada para la evaluación postural de la cabeza en la vista lateral. Veinticinco mujeres jóvenes fueron posicionadas sentadas con la columna erecta y fotografiadas en la vista lateral. Las fotografías fueron importadas por el programa Corel Draw X3 para la evaluación postural mediante fotogrametría computadorizada. Los análisis de confiabilidad intra e inter-examinadores fueron realizadas para los ángulos: cóndilo acromión (ACA), mentón esternón (AME) y Frankfurt (AF). La fotogrametría era realizada por dos examinadores: EA y EB. Para el análisis intra-examinador, el EA hizo la evaluación de las fotos de las participantes dos veces (A1 y A2) para los mismos ángulos un intervalo de tres meses. Para el análisis inter-examinador, el EB evaluó la fotogrametría de los mismos ángulos (B1), la cual se comparó con los datos del EA. Evaluándose el coeficiente de correlación inter-clase (CCI), se observó que hubo una correlación excelente en el análisis intra-examinador (A1 y A2 ) con $\mathrm{CCl}=1,0$ para los ángulos ACA y AME y $\mathrm{CCl}=0,78$ para AF. Hubo una correlación débil en el análisis inter-evaluadores A1 y B1 con un $\mathrm{CCl}$ de 0,24 y 0,26 y entre A2 y B1 con CCl de 0,23; 0,27 y 0,00 para los ángulos de la ACA, AME y AF, respectivamente. Se concluye que la fotogrametría es confiable cuando se realiza por el mismo evaluador. La evaluación inter-examinador mostró baja confiabilidad, lo que puede haber sido comprometido por la experiencia reducida experiencia del EB en la aplicación del método

Palabras clave I Fotogrametría; Postura; Reproducibilidad de los Tests

\section{INTRODUCTION}

All people desire a good body posture, one in which the joints that bare the weight are in alignment and with minimal burden on the muscles and ligaments ${ }^{1-4}$. A poor body alignment can affect the load distribution, providing a pressure on the articular surfaces that can contribute to joint degeneration and inadequate muscle strains ${ }^{3-5}$. Inadequate tension in the cervical region can lead to changes in head position and neck, such as anteriorization, posteriorization, lateralization and cervical rotation ${ }^{3}$.

To check postural asymmetries and prevent deterioration or progression of some cervical dysfunctions one uses the postural evaluation, which is an integral part of a physical therapy routine and aims to determinate possible misalignments and both structural and functional problems in order to plan the conduct and treatment for the postural realignment ${ }^{6,7}$. The main instrument for postural assessment is visual examination, which can be supplemented with the use of photographs ${ }^{8,9}$.

Photography, as documentation of images, helps both clinical practice and scientific studies, it makes the results amenable to measurement and thus makes the analysis occurs objectively and accurately. In the medical field, Kvedar et al. ${ }^{10}$ claim that digital photographic image can replace the dermatologic physical examination in up to $83 \%$ of the cases. For that, it is necessary to have a standardization of the environment and of the camera's position for the correct recording without image distortion and good distinctness ${ }^{11,12}$.

One of the photographical methods for postural assessment with photographic images is computerized photogrammetry ${ }^{13}$. This method provides measurements of body angles from photographs, which allows a quantified postural assessment ${ }^{2,6,14,15}$. Such quantification can be accomplished by using programs like Corel Draw, AutoCAD or $\mathrm{SAPo}^{6,16}$. The use of these programs facilitates the archiving process, with space and also time to access to archived records economy ${ }^{16}$, besides being a method of easy access and low $\operatorname{cost}^{17-19}$.

his tool has been proven effective in the analysis of the most diverse posture research, as can be observed in the following studies. Baraúna et al. ${ }^{20}$ investigated the static balance of transfemoral and transtibial amputees; Lima et al. ${ }^{21}$ found postural changes in mouth breathing children; Manfio et al.22 studied the posture 
of women in barefoot, with low heels and with high heels; Caetano and Nicolau ${ }^{23}$ evaluated postural correction after body awareness and self-stretching.

Due to the wide dissemination of photogrammetry, several studies have examined the reliability and validity of this tool for general postural evaluation ${ }^{2,24}$ through the correlation or consistency of the results. However, the literature on reliability of photogrammetry for cervical postural assessment is scarce. No studies were found on the reliability of photogrammetry in specific angles for the evaluation of the position of the head in anteriorization and in posteriorization, as well as cervical flexion and extension with lateral view. The reliability of a method is verified when it is compared the results obtained from the evaluation of different examiners (interexaminer) for the same subject and when it is evaluated by comparing the evaluation of the results obtained by the same examiner (intraexaminer) $)^{2}$.

In this way, the aim of this study was to assess the intra and interexamiers reliability of computerized photogrammetry for the head postural assessment in a lateral view.

\section{METHODOLOGY}

\section{Ethical considerations}

The development of this study was initiated after the project's approval by the Universidade de São Paulo's Research Ethics Committee. All participants were informed about this study's objectives and procedures, and after agreement signed the consent form.

\section{Casuistry}

In this research were involved 25 young women between 20 and 30 years, mean age 23.32 \pm 2.59 years. Inclusion criteria: not present relevant postural changes, such as thoracic kyphosis, cervical lordosis, scoliosis, exaggerated protrusion of shoulders and exaggerated protrusion of heads; and do not present musculoskeletal diseases in regions of the trunk, head and neck, such as stress, contractures, weaknesses and/or muscle pain in these regions. To collect these informations a classical postural evaluation was conducted by the research's lead author and also through a questionnaire completed by the participants. There was no sample loss in the present study.

\section{Procedures}

For data collection an evaluation form consisting with the individual's name, age and a table for photogrammetric data recording was used. After completing the evaluation form, participants remained seated in an upright position and were asked the following placements: anteriorization and posteriorization from the head; flexion and extension of the cervical spine. The evaluations were performed in the sitting position for it being often harmful to the spine, particularly the cervical spine, even more than the standing position, and because the work position of many professionals that work with computers and/or in worktables ${ }^{13,25}$.

Anatomical points were marked on the skin with circular markers stickers with $9 \mathrm{~mm}$ diameter from the Pimaco brand. The marked points were: mandibular condyle, acromion of the scapula and xiphoid process of the sternum.

The participants were photographed in a left lateral view using a camera of the brand Sony Model Cybershot DSC-P200 7.2 megapixel positioned on a tripod support with height of $1,0 \mathrm{~m}$ and at $1,5 \mathrm{~m}$ from the chair of the subject. The photographs were imported into Corel Draw X3 program to perform the computerized photogrammetry.

From the photogrammetry were defined and investigated three angles related to the positioning of the head and neck, seen in side view, formed by the points previously marked. The angles studied were ${ }^{18}$ :

- Condyle-acromion angle (ACA): angle formed by the intersection of the line formed by the union of the marked points mandibular condyle and the acromion of the scapula with the line perpendicular to the ground.

- Mento-sternal angle (AME): angle formed by the intersection of the line formed by the union of the chin's most anterior point, not marked because of the easy visualization in a lateral view, with the previously marked spot on the xiphoid process with the line perpendicular to the ground.

- Angle of Frankfurt (AF): angle formed by the intersection of the Frankfurt plane line with a line perpendicular to the ground. The Frankfurt plane is the line formed by joining two points no demarcated 
due to easy visualization in lateral view: external auditory canal and lower limit of the eye socket ${ }^{26}$.

These angles were adopted because in a lateral viewing they describe the positions of the head. The AF shows changes in flexion and extension of the head and the ACA and AME angles describe the forward and backwards of the head.

The photogrammetry was conducted by two examiners: examiner A (EA) and examiner B (EB). For the intraexaminer analysis EA took the photos of the participants evaluation twice (A1 and A2) for the same angles and at an interval of three months. To the interexaminers analyze the photoghafs were sent to the EB, which held photogrammetry of the same angles (B1) for comparison with the EA data. Each examiner performed an analysis of each angle for each subject.

Regarding the examiners training, during the realization of this study, the EA had two years of experience in the use of computerized photogrammetry for postural assessment. The EB was trained for the application of the method of photogrammetry through seven days with three hours of training in each, over a period of three weeks.

\section{Statistical analysis}

The obtained data were statistically analyzed by the BioEstat 5.0 Program and the Intraclass Correlation
Coefficient test was used (ICC 1,1$)^{27}$, continuous data for related samples, both for the inter analysis and for the intraexaminer. Was considered a weak correlation when ICC $<0.4$, satisfactory when $0.4 \leq \mathrm{ICC}<0.75$, and excellent when $\mathrm{ICC} \geq 0.75^{28}$.

\section{RESULTS}

The photogrammetry results for the ACA of this study's participants obtained by the evaluator $A$ in his first and second photogrammetric analysis (A1 and A2) and by the evaluator B (B1), as well as the result of intra and interexaminers analyzes by the ICC can be viewed Table 1 .

The AME mean values of this present sample, found by the two photogrammetric analysis of the evaluator A (A1 and A2) and the evaluator B's analysis B (B1), as well as the statistics comparisons with the ICC test for intra and inter- evaluator can be seen in Table 2 .

The AF photogrammetry results for this study's participants obtained by the evaluator $A$, in the first and in the second assessment (A1 and A2) and by the evaluator B (B1) and statistical analyzes intra and interexaminers by the ICC test can be seen in Table 3.

Table 1. Mean values of the condyle-acromion angle, followed by the standard deviation in degrees $\left({ }^{\circ}\right)$, found in photogrammetric analysis by the evaluators $\mathrm{A}(\mathrm{A} 1$ and $\mathrm{A} 2$ ) and B (B1) to the participants of this study and the results of interclass correlation coeficient statistical tests of the intra and inter-raters' comparisons

\begin{tabular}{|c|c|c|c|c|c|c|c|}
\hline \multicolumn{4}{|c|}{ Condyle-acromion angle $\left(^{\circ}\right)$} & \multicolumn{4}{|c|}{ ICC } \\
\hline & A1 & $\mathrm{A} 2$ & B1 & Comparison & $\mathrm{A} 1 \times \mathrm{A} 2$ & $\mathrm{~A} 1 \times \mathrm{B} 1$ & $\mathrm{~A} 2 \times \mathrm{B} 1$ \\
\hline Average value & 25.84 & 26 & 22.56 & Result & 1.00 & 0.24 & 0.23 \\
\hline Standard deviation & 7.60 & 7.65 & 4.51 & Correlation & excellent & weak & weak \\
\hline
\end{tabular}

ICC: interclass correlation coeficient

Table 2. Mean values of the Chin-sternal angle, followed by the standard deviation in degrees $\left(^{\circ}\right)$ found in photogrammetric analysis by the evaluators A (A1 and $\mathrm{A} 2$ ) and $\mathrm{B}(\mathrm{B} 1)$ of the participants of this study and the results of interclass correlation coeficient statistical tests of the intra and inter-raters' comparisons

\begin{tabular}{|c|c|c|c|c|c|c|c|}
\hline \multicolumn{4}{|c|}{ Chin-sternal angle $\left(^{\circ}\right)$} & \multicolumn{4}{|c|}{ ICC } \\
\hline & $\mathrm{A} 1$ & $\mathrm{~A} 2$ & B1 & Comparison & $\mathrm{A} 1 \times \mathrm{A} 2$ & $\mathrm{~A} 1 \times \mathrm{B} 1$ & $\mathrm{~A} 2 \times \mathrm{B} 1$ \\
\hline Average value & -0.68 & -0.24 & -1.80 & Result & 1.00 & 0.26 & 0.27 \\
\hline Standard deviation & 8.15 & 7,48 & 5.18 & Correlation & excellent & weak & weak \\
\hline
\end{tabular}

ICC: interclass correlation coeficient

Tabela 3. Mean values of the Frankfurt Angle (AF), followed by the standard deviation in degrees $\left(^{\circ}\right)$ found in photogrammetric analysis by the evaluators A (A1 and $\mathrm{A} 2$ ) and $\mathrm{B}$ (B1) of the participants of this study and the results of interclass correlation coeficient statistical tests of the intra and inter-raters' comparisons.

\begin{tabular}{lcccccccccc} 
& \multicolumn{1}{c}{ Frankfurt angle $\left(^{\circ}\right)$} & & & & ICC \\
& A1 & A2 & B1 & & Comparison & & A1 x A2 & A1 x B1 & A2 x B1 \\
Average value & 89.84 & 88.96 & 80.00 & & Result & 1.00 & 0.26 & 0.27 \\
Standard deviation & 6.60 & 4.60 & 6.88 & & Correlation & excellent & weak & weak
\end{tabular}




\section{DISCUSSION}

In the present study, the investigation of intra and interexaminers reliability of photogrammetry for postural analysis of head and cervical spine was performed through the evaluation of women in the sitting position. McEvoy and Grimmer ${ }^{13}$ highlighted that there is great interest in the study of body posture in sitting position, as this position is adopted by professionals using visual monitors and can lead to musculoskeletal disorders with consequent losses in the worker output.

The analyzes used here are restricted to lateral view for enabling better perception of anteriorization and posteriorization of the head. Analysis of the posture in a lateral view in the study were previously performed by Carneiro and Teles ${ }^{18}$ to study anteriorization of the head. In a previous study, Pasinato et al. ${ }^{29}$ evaluated the roll angle of the head of subjects with and without temporomandibular dysfunction and rated an angle that they called vertical, which describes an anteriorization or a posteriorization of the head.

The program used in this research for photogrammetry was Corel Draw X3. The reliability of the Corel Draw, AutoCAD e SAPo programs for analysis of photogrammetry was evaluated in the studies of Sacco et al. ${ }^{16}$ and of Guariglia et al. ${ }^{30}$, who have concluded that the three programs studied are reliable. The repeatability of photogrammetry was tested by Carneiro and Teles ${ }^{18}$ with the Corel Draw 10 program for the analysis of 9 body angles of the cervical spine and upper trunk in a lateral view of the same individual over 25 non-consecutive days. They concluded that the method was reliable for eight of nine studied angles.

Regarding the results of the reliability of computerized photogrammetry for the measures of the angles of the head position in a lateral view of the present study, excellent reliability in intraexaminer evaluation and weak interavaluator reliabilities were observed. Similar results were described by Fedorak et al. ${ }^{31}$ when they assessed the reliability of the postural evaluation through photo visualization. However, there are other studies that showed acceptable levels for reliability for both intra and interevaluator reviews. In the study of Iunes et al. ${ }^{6}$, of the 22 angles evaluated by two reviewers, 17 had high levels of reliability and 5 not acceptable levels of reliability. These authors concluded that the method has significant reliability. Other studies have also found excellent results in the study of the reliability of the computerized photogrammetry intra and interexaminator ${ }^{32,33}$. Santos et al. ${ }^{24}$ described $80 \%$ of agreement among 3 reviewers for photogrammetric analysis in a study that had 122 children submitted to a unique photographic record for postural assessment in anterior frontal, posterior, left and right sagittal planes. The authors emphasized that the examiners were trained during a preliminary study, which enabled the high reliability.

The poor inter-rater assessment reliability reported in the present study can be justified by the fact that the examiner A had two years' experience, while the examiner B had his first contact with the computerized photogrammetry in a seven days training divided into a period of three weeks that preceded the experiment. Although photogrammetry is performed from anatomical points previously marked, the research of the analyzed body angles depends on the examiner's practice. This fact highlights the importance of training of the professional that will use this tool for postural assessment. No studies were found in the literature that could guide as to the type and to the length of the training so that an examiner would be qualified to perform the postural evaluation by photogrammetry.

\section{CONCLUSION}

The computerized photogrammetry for the head position's angles measures shows excellent intraexaminer reliability and poor interexaminer reliability in assessment. The weak interexaminer reliability observed in this study may alert you to the need for the examiner's training, a fact essential both for the credibility of clinical physiotherapy as to the reliability of research in rehabilitation.

\section{REFERENCES}

1. Staes FF, Jansen L, Vilette A, Coveliers Y, Daniels K, Decoster W. Physical therapy as a means to optimize posture and voice parameters in student classical singers: a case report. J Voice. 2011;25(3):91-101.

2. Braz RG, Goes FPDC, Carvalho GA. Confiabilidade e validade de medidas angulares por meio do software para avaliação postural. Fisioter Mov. 2008;21(3):117-26.

3. Amantéa DV, Novaes AP, Campolongo GD, Barros TP. A importância da avaliação postural no paciente com disfunção da articulação temporomandibular. Acta Ortop Bras. 2004:12(3):155-9. 
4. Penha PJ, Casarotto RA, Sacco ICN, Marques AP, João SMA. Qualitative postural analysis among boys and girls of seven to ten years of age. Rev Bras Fisioter. 2008:12(5):386-91.

5. Krishnamoorthy V, Latash ML, Scholz JP, Zatsiorsky M. Muscle synergies during shifts of the center of pressure by standing persons. Exp Brain Res. 2003;152(3):281-92

6. Iunes DH, Castro FA, Salgado HS, Moura IC, Oliveira AS, BevilacquaGrossi D. Confiabilidade intra e interexaminadores e repetibilidade da avaliação postural pela fotogrametria. Rev Bras Fisioter. 2005;9(3):327-34.

7. Rodrigues ACC, Romeiro CAP, Patrizzi LJ. Avaliação da cifose torácica em mulheres idosas portadoras de osteoporose por meio da biofotogrametria computadorizada. Rev Bras Fisioter. 2009;13(3):205-9.

8. Gangnet N, Pomero V, Dumas R, Skalli W, Vital JM. Variability of the spine and pelvis location with respect to the gravity line: a threedimensional stereoradiographic study using a force platform. Surg Radiol Anat. 2003;25(5-6):424-33

9. Ferronato A, Candotti CT, Silveira RP. A incidência de alterações no equilíbrio estático da cintura escapular em crianças entre 7 e 14 anos. Mov. 1998;5(9):24-30.

10. Kvedar JC, Edwards RA, Menn ER, Mofid M, Gonzalez E, Dover J, et al. The substitution of digital images for dermatologic physical examination. Arch Dermatol. 1997:133(2):161-7.

11. Hochman B, Nahas FX, Ferreira LM. Fotografia aplicada na pesquisa clínico-cirúrgica. Acta Cir Bras. 2005;20(Suppl. 2):19-25.

12. Hochman B, Castilho HT, Ferreira LM. Padronização fotográfica e morfométrica na fotogrametria computadorizada do nariz. Acta Cir Bras. 2002;17(4):258-66

13. McEvoy MP, Grimmer K. Reliability of upright posture measurements in primary school children. BMC Musculoskelet Disord. 2005;6:35.

14. Döhnert MB, Tomasi E. Validade da fotogrametria computadorizada na detecção de escoliose idiopática adolescente. Rev Bras Fisioter. 2008;12(4):290-7.

15. Iunes DH, Bevilaqua-Grossi ID, Oliveira AS, Castro FA, Salgado HS. Análise comparativa entre avaliação postural visual e por fotogrametria computadorizada. Rev Bras Fisioter. 2009;13(4): 308-15.

16. Sacco ICN, Alibert S, Queiroz BWC, Pripas D, Kieling I, Kimura AA, et al. Confiabilidade da fotogrametria em relação à goniometria para avaliação postural de membros inferiores. Rev Bras Fisioter. 2007:11(5):411-7.

17. Coelho Júnior AN, Gazzola JM, Gabilan YPL, Mazzetti KR, Perracini MR, Ganança FF. Alinhamento de cabeça e ombros em pacientes com hipofunção vestibular unilateral. Rev Bras Fisioter. 2010;14(4):330-6.

18. Carneiro PR, Teles LCS. Influência de alterações posturais, acompanhadas por fotogrametria computadorizada, na produção da voz. Fisioter Mov. 2012;25(1):13-20.
19. Miranda R, Schor E, Grão MJBC. Avaliação postural em mulheres com dor pélvica crônica. Rev Bras Ginecol Obstet. 2009;31(7):353-60.

20. Baraúna MA, Duarte F, Sanchez HM, Canto RST, Malusá S, CampeloSilva CD, et al. Avaliação do equilíbrio estático em indivíduos amputados de membros inferiores através da biofotogrametria computadorizada. Rev Bras Fisioter. 2006;10(1):83-90.

21. Lima LC, Baraúna MA, Sologurem MJ, Canto RS, Gastaldi AC. Postural alterations in children with mouth breathing assessed by computerized biophotogrammetry. J Appl Oral Sci. 2004;12(3):232-7.

22. Manfio EF, Vilardi Junior NP, Abrunhosa VM, Souza LV, Fernandes BM, Pereira RM. Alterações na marcha descalça e com salto alto. Anais do X Congresso Brasileiro de Biomecânica; Belo Horizonte, Minas Gerais: UFMG, 2003;:87-90.

23. Caetano RC, Nicolau RA. Avaliação da correção postural após conscientização corporal e auto alongamento por fotogrametria computadorizada. Ter Man. 2011;9(41):29-36.

24. Santos MM, Silva MPC, Sanada LS, Alves CRJ. Análise postural fotogramétrica de crianças saudáveis de 7 a 10 anos: confiabilidade interexaminadores. Rev Bras Fisioter. 2009;13(4):350-5.

25. Braccialli LMP, Vilarta R. Aspectos a serem considerados na elaboração de programas de prevenção e orientação de problemas posturais. Rev Paul Educ Fís, 2000:14(2):159-71.

26. Marques RM. Avaliação fisioterapêutica da postura natural da cabeça e pescoço em portadores de disfunções da articulação temporomandibular por meio da fotometria e radiografia [dissertação]. Bauru (SP): Universidade do Sagrado Coração; 2003.

27. Weir, JP. Quantifying test-retest reliability using the intraclass correlation coefficient and the SEM. J Stren Cond Res. 2005;19(1):231-40,

28. Fleiss, JL. The design and analysis of clinical experiments. New York: Wiley; 1986

29. Pasinato F, Corrêa ECR, Souza JA. Avaliação fotogramétrica da postura da cabeça e coluna cervical de indivíduos com disfunção temporomandibular. Ter Man. 2009;7(29):47-53.

30. Guariglia DA, Pereira LM, Pereira HM, Cardoso JR. Avaliação da confiabilidade e usabilidade de três diferentes programas computacionais para a análise fotogramétrica do ângulo de flexão de quadril. Fisioter Pesqui. 2011;18(3):247-51.

31. Fedorak C, Ashworth N, Marshall J, Paull H. Reliability of the visual assessment of cervical and lumbar lordosis: how good are we? Spine. 2003:28(16):1857-9.

32. Mendonça AMS, Pádua M, Ribeiro AP, Milani GB, João SMA. Confiabilidade intra e interexaminadores da fotogrametria na classificação do grau de lipodistrofia ginoide em mulheres assintomáticas. Fisioter Pesqui. 2009;16(2):102-6.

33. Normand MC, Descarreaux M, Harrison DD, Harrison DE, Perron DL, Ferrantelli JR, et al. Three dimensional evaluation of posture in standing with the posture print: an intra- and inter-examiner reliability study. Chipor Osteopat. 2007;15:15. 